\title{
Evaluation of the Wear Resistance and Corrosion Behavior of Laser Cladding Al/SiC Metal Matrix Composite Coatings on ZE41 Magnesium Alloy
}

\author{
Ainhoa Riquelme *, Pilar Rodrigo, María Dolores Escalera-Rodriguez (D) and Joaquín Rams (D) \\ Escuela Superior de Ciencias Experimentales y Tecnología, Ciencia e Ingeniería de Materiales, Universidad Rey \\ Juan Carlos, 28933 Madrid, Spain; pilar.rodrigo@urjc.es (P.R.); dolores.escalera@urjc.es (M.D.E.-R.); \\ joaquin.rams@urjc.es (J.R.) \\ * Correspondence: ainhoa.riquelme.aguado@urjc.es
}

Citation: Riquelme, A.; Rodrigo, P.; Escalera-Rodriguez, M.D.; Rams, J. Evaluation of the Wear Resistance and Corrosion Behavior of Laser Cladding $\mathrm{Al} / \mathrm{SiC}$ Metal Matrix Composite Coatings on ZE41 Magnesium Alloy. Coatings 2021, 11, 639. https://doi.org/10.3390/ coatings11060639

Academic Editor: Charafeddine Jama

Received: 28 April 2021

Accepted: 20 May 2021

Published: 27 May 2021

Publisher's Note: MDPI stays neutral with regard to jurisdictional claims in published maps and institutional affiliations.

Copyright: (c) 2021 by the authors. Licensee MDPI, Basel, Switzerland. This article is an open access article distributed under the terms and conditions of the Creative Commons Attribution (CC BY) license (https:// creativecommons.org/licenses/by/ $4.0 /)$.

\begin{abstract}
Aluminum matrix composites reinforced with SiC particles (SiCp) were deposited on ZE41 magnesium substrates by laser cladding in order to improve their tribological performance. Silicon and titanium were added to the matrix in order to avoid Al-SiC reactivity. The addition of these elements to avoid $\mathrm{Al}_{4} \mathrm{C}_{3}$ formation during the laser cladding fabrication was successfully explored in previous research, but the effect of these elements on the wear behavior and the corrosion resistance of these coatings has not been studied. During the fabrication process, there is dilution with the substrate that forms an Al-Mg matrix, which has an influence on the wear and corrosion behavior. Electrochemical polarization and impedance measurements in a $3.5 \% \mathrm{NaCl}$ solution and the dry sliding conditions on a pin-on-disc tribometer were used to evaluate the different compositions of $\mathrm{Al} / \mathrm{SiCp}$ coatings on the ZE41 magnesium alloy and uncoated ZE41. All of the composite coatings had lower wear rates than the substrate. However, the coatings showed worse corrosion behavior than the ZE41 substrate, although the addition of Si or Ti improves the corrosion behavior and the wear resistance.
\end{abstract}

Keywords: laser cladding; MMC coatings; ZE41; wear; corrosion

\section{Introduction}

The growth of social ecological awareness has led the aerospace and automobile sectors to find new solutions for weight reduction, and to increase the properties of lightweight materials. Magnesium alloys cousld be a good candidate to replace conventional materials but their use is limited by their high mechanical requirements. As such, the development of new materials with improved properties is mandatory [1-4].

Aluminum matrix composites reinforced with $\mathrm{SiC}$ particles $(\mathrm{Al} / \mathrm{SiC})$ are a reference material due to their favorable mechanical properties [5-7]. The possibility of the fabrication of $\mathrm{Al} / \mathrm{SiC}$ coatings on magnesium alloys could be a possible solution to obtain light components with high tribological properties [8,9]. The incorporation of a ceramic phase into a matrix can enhance the physical and mechanical properties of the latter. However, it can also change its corrosion behavior. Several factors determine the corrosion behaviour of metal-matrix composites, such as the composition of the matrix alloy and its microstructure, the reinforcement dispersion, and the technique used to fabricate the composite [10].

Laser cladding is an effective fabrication process to obtain composite coatings compared to conventional methods [11,12]. However, the $\mathrm{Al} / \mathrm{SiC}$ deposition by laser cladding involves a reactivity problem due to the high energy provided to the coating during the $\mathrm{Al}$ and the $\mathrm{SiC}$ reaction to form $\mathrm{Al}_{4} \mathrm{C}_{3}$ and $\mathrm{Si}$. The $\mathrm{Al}_{4} \mathrm{C}_{3}$ formation must be avoided because it is a brittle and hygroscopic intermetallic [13-18] that may degrade the mechanical and corrosion behavior. Thus, it is important to avoid the formation of $\mathrm{Al}_{4} \mathrm{C}_{3}$ in this kind of composite. In previous research, laser cladding with $\mathrm{Al} / \mathrm{SiC}$ on magnesium alloy was 
successfully carried out and the effect of the addition of other alloying elements (silicon and titanium) to the matrix of the composite coating was investigated [19]. The addition of silicon and/or titanium can avoid the $\mathrm{Al}_{4} \mathrm{C}_{3}$ formation and, in addition, the presence of these elements in the composite matrix can increase their microhardness. However, the effects of these elements on the wear behavior or the corrosion resistance of these coatings have not been analyzed.

During the fabrication process, there is a dilution between the magnesium and the aluminum, and it produces the formation of a novel $\mathrm{Al}-\mathrm{Mg}$ matrix characterized by dendrites of $\mathrm{Mg}_{2} \mathrm{Si}$ and a eutectic constituent formed by $\mathrm{Al}_{12} \mathrm{Mg}_{17}-\mathrm{Mg}$ and $\mathrm{Al}_{12} \mathrm{Mg}_{17}$ [19].

The addition of silicon into the $\mathrm{Al}$ matrix increases the Si activity, inhibiting the aluminum carbide formation [20-22] and, therefore, the silicon carbide consumption during the cladding process. The addition of $40 \mathrm{wt} . \% \mathrm{Si}$ into the $\mathrm{Al} / \mathrm{SiC}$ composite matrix inhibits the $\mathrm{Al}_{4} \mathrm{C}_{3}$ formation. Furthermore, the addition of $20 \mathrm{wt}$ \% Ti avoids the presence of $\mathrm{Al}_{4} \mathrm{C}_{3}$ in the composite matrix [19,23-25].

The mechanical and corrosion behavior of metal-matrix composites is determined by several factors, such as the composition of the alloy, the matrix microstructure, the dispersoid, the matrix and the technique adopted for the preparation of the composite $[10,26]$. These factors, especially the formation of different phases in the composite matrix, due to the incorporation of $\mathrm{Si}$ and $\mathrm{Ti}$ to avoid the $\mathrm{Al}-\mathrm{SiC}$ reactivity problems, could seriously affect the mechanical and corrosion characteristics of the metal.

The present study describes and compares the wear behavior of the ZE41 magnesium alloy and different compositions of $\mathrm{Al} / \mathrm{SiC}$ composite coatings deposited on this alloy. Furthermore, the corrosion resistance of these materials in a $3.5 \% \mathrm{NaCl}$ solution at room temperature was analyzed. The evolution of the corrosion behavior with the immersion time was studied and different corrosion mechanisms were proposed.

\section{Materials and Methods}

Different compositions of $\mathrm{Al} / \mathrm{SiCp}$ coatings on ZE41 magnesium alloy were deposited. A commercial powder of aluminum, silicon carbide, silicon and titanium (Table 1) was mixed on a ball mill in an alumina jar with $2 \mathrm{~cm}$ diameter alumina balls for $5 \mathrm{~h}$, with different proportions, in order to obtain different composite powders (Table 2). ZE41 coupons of $45 \times 45 \times 10 \mathrm{~mm}^{3}$ with a T5 treatment were used as substrate. The main alloying elements of the ZE41 were (in wt.\%): 4.09Zn; 1.68 rare earths $(\mathrm{Pr}+\mathrm{Nd}+\mathrm{L}+\mathrm{Ce}$ ); $0.68 \mathrm{Zr} ; 0.6 \mathrm{O} ; 0.03 \mathrm{Mn}$, and a balance of $\mathrm{Mg}$. The surface of the substrates was mechanically polished, and then they were immersed in 10 vol. $\% \mathrm{H}_{2} \mathrm{SO}_{4}$ solution at $25^{\circ} \mathrm{C}$ for $5 \mathrm{~s}$.

Table 1. Powder properties.

\begin{tabular}{cccc}
\hline Product & Supplier & D50 $(\mu \mathrm{m})$ & $\rho\left(\mathbf{g} \cdot \mathbf{c m}^{-\mathbf{3}}\right)$ \\
\hline $\mathrm{Al} 12 \mathrm{wt} . \% \mathrm{Si}$ & Metco 52C-NS & 71 & 2.7 \\
$\mathrm{SiC}$ & Navarro S.A F-360 & 26 & $2-2.3$ \\
$\mathrm{Si}$ & Alfa Aesar & 44 & 2.3 \\
$\mathrm{Ti}$ & Alsa Aesar & 100 & 4.5 \\
\hline
\end{tabular}

Table 2. Cladding powder proportions.

\begin{tabular}{cc}
\hline Percentage & Abbreviated Name \\
\hline Al1 2 wt. $\%$ Si-0 wt. $\% \mathrm{SiC}$ & Al12Si $/ \mathrm{SiC}$ \\
$\mathrm{Al} 40$ wt. $\% \mathrm{Si}-30$ wt. $\% \mathrm{SiC}$ & $\mathrm{Al} 40 \mathrm{Si} / \mathrm{SiC}$ \\
$\mathrm{Al} 12 \mathrm{Si}$ wt. $\%-20$ wt. $\%$ Ti-30 wt. $\% \mathrm{SiC}$ & Al12Si20Ti/SiC \\
\hline
\end{tabular}

The coatings were prepared by laser cladding using a $1300 \mathrm{~W}$ and a 808-940 nm wavelength continuous wave diode laser (ROFIN DL013S, Santa Clara, CA, USA) connected to an ABB IRB2400 robot (Asea Brown Boveri, Zurich, Switzerland) with a coaxial nozzle Fraunhofer IWS COAX 8 nozzle (Fraunhofer Institute for Material and Beam Technology, 
Winterbergstraße, Dresden, Germany). The processing parameters used were optimized using preliminary research [19]. Table 3 shows the laser control parameters used during the test. After the cladding deposition, the specimens were cross-sectioned and polished for the analysis of their microhardness and their microstructure profile. The cross-sections of the samples were cut, mounted in an electrically conductive resin, wet ground using a sequence of abrasive silicon carbide (400 to 4000 grit) and, finally, polished using a $1 \mu \mathrm{m}$ diamond and ethylene glycol as a lubricant. The microstructure and phase analysis were examined using a scanning electron microscope (SEM) from Hitachi S3400N (Tokyo, Japan) equipped with an energy dispersive X-ray spectrometer (EDS) from Brucker AXS X flash Detector 5010 (Billerica, MA, USA). In addition, a Shimadzu microhardness tester was used to obtain the Vickers microhardness $\left(\mathrm{HV}_{0.5}\right.$ for a loading time of $\left.15 \mathrm{~s}\right)$ of the specimens.

Table 3. Fabrication control parameters.

\begin{tabular}{ccccc}
\hline $\begin{array}{c}\text { Laser } \\
\text { Power }(\mathbf{W})\end{array}$ & $\begin{array}{c}\text { Scan Speed } \\
(\mathbf{m m} / \mathbf{s})\end{array}$ & $\begin{array}{c}\text { Distance between } \\
\text { Consecutive Laser } \\
\text { Lines }(\mathbf{m m})\end{array}$ & $\begin{array}{c}\text { Powder Feed Rate } \\
(\mathrm{g} / \mathbf{m i n})\end{array}$ & $\begin{array}{c}\text { Focal Position of } \\
\text { the Laser Beam } \\
(\mathbf{m m})\end{array}$ \\
\hline 650 & 17 & 0.7 & 3 & 0 \\
\hline
\end{tabular}

The wear tests were carried out on the surface of the uncoated ZE41 and the different clad coatings under dry sliding conditions on a pin-on-disc tribometer (Microtest MT/10/SCM) using a $10 \mathrm{~N}$ load, $4 \mathrm{~mm}$ diameter and $200 \mathrm{rpm}$ for a total wear length of $1000 \mathrm{~m}$. The wear testing machine continuously recorded the friction coefficient. The mass loss was measured using a Sartorius BP 211S balance with a precision of $\pm 0.0001 \mathrm{~g}$. Furthermore, the wear rate was determined by image analysis using a Z20 3D Optical profiler. Archard's law (Equation (1)) allowed us to evaluate the different wear mechanisms:

$$
\frac{V}{L}=K \frac{W}{H}
$$

where $V$ is the wear volume, $L$ is the sliding distance, the coefficient $V / L$ is the wear rate, $W$ is the applied load and $H$ is the hardness of the sample.

The debris formed and the wear tracks on the surface and on the metallographically prepared transversal section were analyzed by SEM and EDS. The worn surfaces and debris obtained after the wear tests using different sliding distances $(200,500$ and $1000 \mathrm{~m})$ were compared in order to determine the evolution of the different wear mechanisms.

The corrosion behavior of the $\mathrm{Al} / \mathrm{SiC}$ coatings on $\mathrm{ZE} 41$ magnesium alloy was evaluated and compared with the uncoated substrate. The electrochemical measurements were taken in an aerated $3.5 \mathrm{wt} . \% \mathrm{NaCl}$ solution using an Autolab PGStat 30 (Metrohm AG, Herisau, Switzerland) exposing an area of $0.78 \mathrm{~cm}^{2}$ of the sample to the test medium. All of the electrochemical tests were carried out at room temperature without stirring. A threeelectrode cell was used for the electrochemical measurements; the working electrode was the tested material, and the counter and reference electrodes were graphite and silver/silver chloride $(\mathrm{Ag} / \mathrm{AgCl})$, respectively. The anodic-cathodic polarization measurements were carried out at $0.016 \mathrm{~V} / \mathrm{s}$ scan rate from -0.01 to $0.015 \mathrm{~V}$ with respect to $E_{\text {corr }}$. A potential of $\pm 20 \mathrm{mV}$ around the corrosion potential $\left(E_{c o r r}\right)$ with a $1 \mathrm{mV} / \mathrm{s}$ scanning rate was applied for different immersion times in the electrolyte in order to calculate the polarization resistance $\left(R_{p}\right)$. The corrosion products generated after the immersion test were analysed by an SEM equipped with EDS.

\section{Results and Discussion}

\subsection{Coatings Microstructure}

The Al12Si/SiC coating microstructure analyzed by SEM is shown in Figure 1. A good metallurgical interface between the substrate and coating can be observed in the cross-section (Figure 1a). The deposition efficiency can be calculated from the ratio between 
the deposited cross-section area, the scanning speed, the sprayed powder density, and the powder feed ratio [27].

$$
\text { Deposition efficiency }=\frac{\text { deposited cross }- \text { section area } \cdot \text { scanning speed } \cdot \text { powder density }}{\text { Powder feed ratio }}
$$
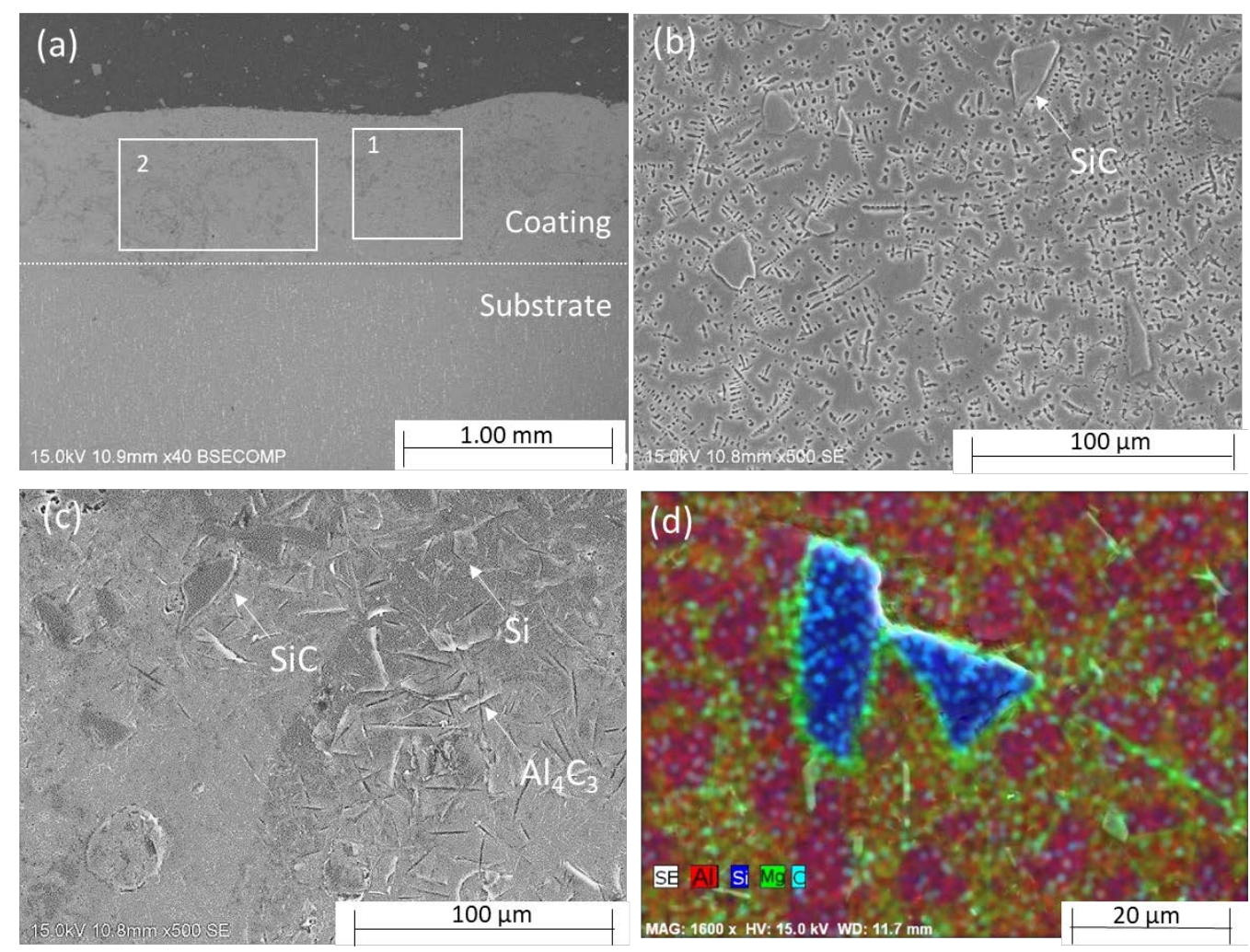

Figure 1. Al12Si/SiC coating: (a) cross-section, (b) detail of zone 1 of the coating, (c) detail of zone 2 of the coating; (d) EDX map of the surface shown in (c).

According to this equation, the deposition efficiency of the Al12Si/SiC coating was $19 \%$. This value is similar to the efficiencies obtained by other deposition techniques of composite materials such as [28,29].

The microstructure was characterized in the zones that showed different compositions (Figure $1 \mathrm{~b}, \mathrm{c}$ ). In both cases, the composite matrix was mainly formed by dendrites of $\mathrm{Mg}_{2} \mathrm{Si}$ and a eutectic constituent formed by $\mathrm{Al}_{12} \mathrm{Mg}_{17}-\mathrm{Mg}$ and $\mathrm{Al}_{12} \mathrm{Mg}_{17}$ [19]. These dendrites can be observed in Figure 1d. Some zones of the coating (Figure 1b) present a higher percentage of magnesium than others (Figure 1c). In Figure 1b, it can be seen that in zone 1 , the only phase apart from the matrix is the $\mathrm{SiC}$ reinforcement particles. However, in Figure $1 \mathrm{c}-$ where a detail of zone 2 of the coatings can be observed- $\mathrm{Al}_{4} \mathrm{C}_{3}$ and $\mathrm{Si}$, apart from the $\mathrm{SiC}$ and the matrix, can be observed. The reason for these differences observed in the coating is that during the fabrication process, the solidification was too fast and the diffusion flows were not enough to incorporate the diluted magnesium from the substrate homogenously into the coating [19].

The addition of Si or Ti to the alloy changes the microstructure of the coating. The Al40Si/SiC and Al12Si-Ti/SiC coating presents a good metallurgical substrate-coating interface, as can be seen in Figure 2a,b. The deposition efficiency of the Al40Si/SiC coating was 33\%, and $19 \%$ in the case of the Al12Si-Ti/SiC coating. As in the case of $\mathrm{All} 2 \mathrm{Si} / \mathrm{SiC}$, for the Al40Si/SiC coating (Figure 2c,e) the composite matrix was formed by $\mathrm{Mg}_{2} \mathrm{Si}, \mathrm{Al}_{12} \mathrm{Mg}_{17^{-}}$ $\mathrm{Mg}$, and $\mathrm{Al}_{12} \mathrm{Mg}_{17}$. In addition, the $\mathrm{SiC}$ particles were not degraded and there was no presence of $\mathrm{Al}_{4} \mathrm{C}_{3}$. However, the $\mathrm{SiC}$ matrix interface showed discontinuities because the wettability decreased [19]. The Al12Si-Ti/SiC coating (Figure 2d,f) was characterized by a $\mathrm{Mg}_{2} \mathrm{Si}, \mathrm{Al}_{12} \mathrm{Mg}_{17}-\mathrm{Mg}$ and $\mathrm{Al}_{12} \mathrm{Mg}_{17}$ matrix. Ti only reacts with $\mathrm{Al}$ and $\mathrm{Si}$ to form 
$\mathrm{TiSi}_{2}$ and $\mathrm{AlTi}_{3}$. There was no eutectic Si due to all of the silicon reacting with titanium and magnesium [19].
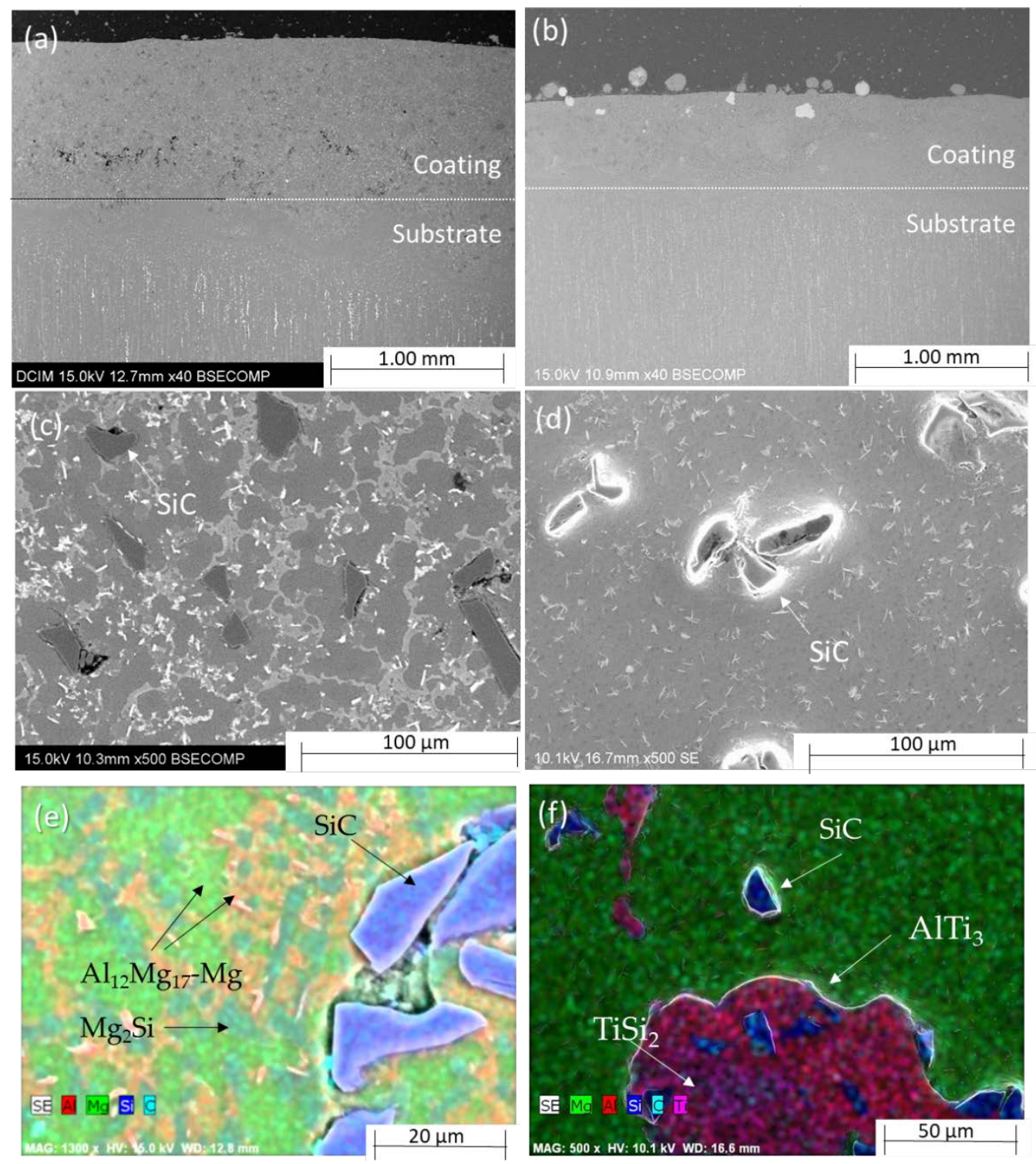

Figure 2. Microstructure of (a) Al40Si/SiC coating, cross-section; (b) Al12Si-Ti/SiC coating, crosssection; (c) detail of Al40Si/SiC microstructure; (d) detail of the Al12Si-Ti/SiC microstructure; (e) EDX map of the Al40Si/SiC surface; (f) EDX map of the Al12Si-Ti/SiC surface.

\subsection{Wear Testing}

Figure 3 shows the wear test measurements of the different samples using a $10 \mathrm{~N}$ load, a $4 \mathrm{~mm}$ diameter, and $200 \mathrm{rpm}$ for a total wear length of $1000 \mathrm{~m}$. 
(a)

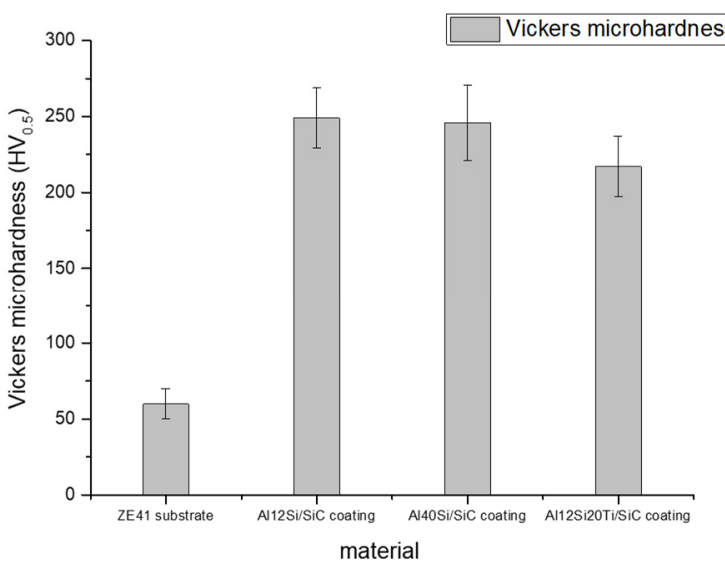

(b)

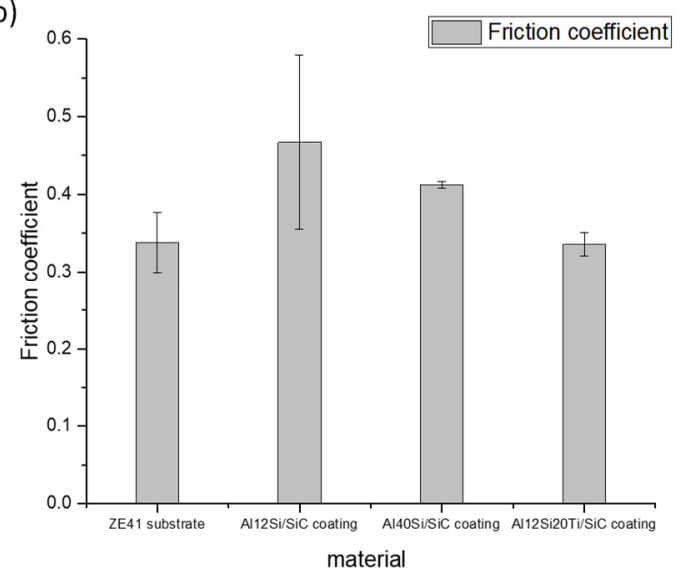

(c)

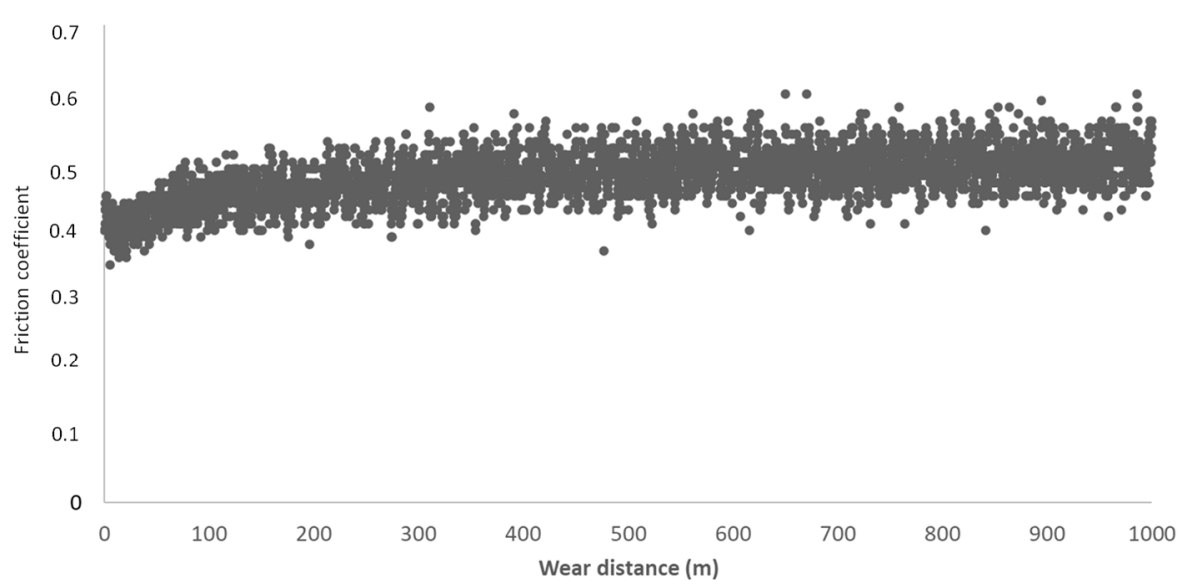

(d)

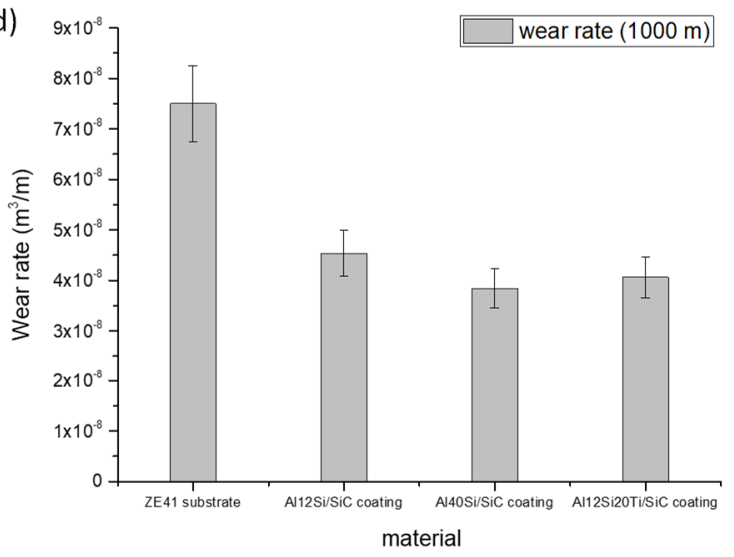

(f)

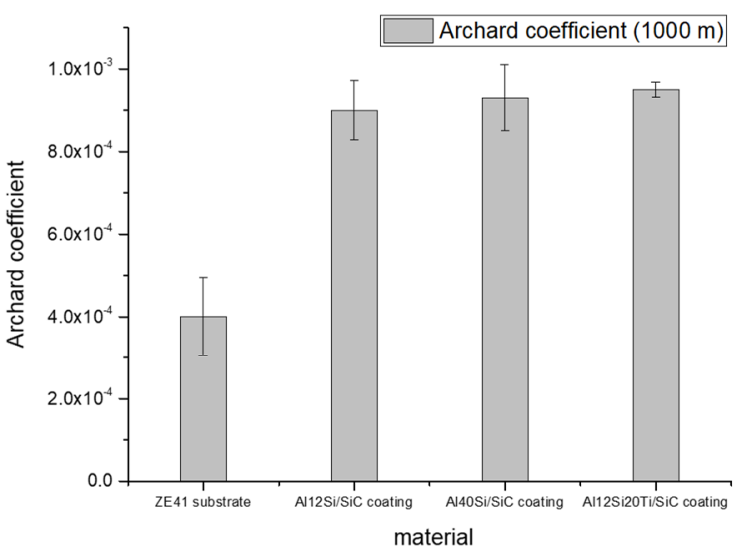

Figure 3. Wear test measurements for the substrate and coatings on the ZE41 magnesium alloy: (a) microhardness; (b) friction coefficient; (c) friction coefficient vs. wear distance for Al12Si/SiC coating; (d) wear rate; (f) Archard coefficient.

The average microhardness is shown in Figure 3a. All of the coatings have a higher microhardness than the uncoated ZE41 magnesium alloy. The microhardness increase was higher than $\times 4$ in the case of $\mathrm{Al12Si} / \mathrm{SiC}$ and $\mathrm{Al} 40 \mathrm{Si} / \mathrm{SiC}$, and $\times 3.5$ in the case of the Al12Si20Ti/SiC with respect to the uncoated ZE41. The hardness is similar in Al12Si/SiC and $\mathrm{Al} 40 \mathrm{Si} / \mathrm{SiC}$, but the standard deviation is lower in the Al40Si/SiC coatings because their microstructure was more homogenous than that in the Al12Si/SiC. In addition, despite $\mathrm{Al}_{4} \mathrm{C}_{3}$ increasing the coating's hardness, these components could be hydrated, which can reduce the mechanical properties of the coating. The Al12Si20Ti/SiC coating's 
microhardness is slightly lower than the others because the Al-SiC-Ti reactivity forms phases with lower hardness.

The friction coefficient is shown in Figure $3 b$. The friction coefficient is higher in the Al12Si/SiC and Al40Si/SiC coatings than in the ZE41 substrate and Al12Si20Ti/SiC (which have similar friction coefficients). The Al12Si/SiC friction coefficient is $27 \%$ higher than that of uncoated ZE41. The presence of $\mathrm{Al}_{4} \mathrm{C}_{3}$ in the $\mathrm{Al12Si} / \mathrm{SiC}$ coating produces a higher friction coefficient because the $\mathrm{Al}_{4} \mathrm{C}_{3}$ breaks loose and produces abrasive wear. In the Al40Si/SiC coatings, the friction coefficient is $18 \%$ higher than that of the ZE41 substrate. In this case, it is because the primary silicon particles break loose. In the Al12Si20 Ti/SiC coatings, the friction coefficient is similar to the uncoated ZE41. The breaking loose of small phases is lower and, consequently, the friction coefficient is similar to that of the substrate. Figure $3 \mathrm{c}$ shows the friction coefficient evolution as a function of the wear distance. A stabilization of the friction coefficient value from the first $100 \mathrm{~m}$ of the wear test can be seen.

Figure $3 \mathrm{~d}$ shows the wear rate for the substrate and coatings on a ZE41 magnesium alloy. The coated materials' wear rates were $40 \%$ lower than the uncoated substrate. Generally, the wear rate is inversely proportional to the microhardness. The differences in the wear rate of the coatings are due to the matrix-reinforcement interface resistance, apart

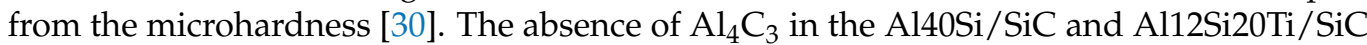
coating microstructure produces a higher matrix-reinforcement interface resistance and a lower wear rate $(10.8 \%$ and $7.1 \%$ lower, respectively, in comparison with the Al12Si $/ \mathrm{SiC}$ coating) despite the lower microhardness ( $1.25 \%$ and $12.85 \%$, respectively).

In addition, the Archard coefficient (Figure 3f) allows the determination of the presence of different wear mechanisms. The wear mechanism is different between the substrate and the coatings.

\subsection{Wear Mechanisms}

In order to identify the different mechanisms that take place during the wear of the substrate and the coatings, the worn surfaces and the wear debris were observed by SEM. In addition, the evolution of the wear mechanism was evaluated by comparing the worn surface to the sliding distance $(200,500$, and $1000 \mathrm{~m})$. Figure 4a shows a comparison of the SEM micrographs of the worn surfaces of the uncoated ZE41 and the different coatings (Al12Si/SiC, Al40Si/SiC, and Al12Si20Ti/SiC) against the sliding distance.

In all cases, many fine grooves parallel to the sliding direction can be observed on the worn surface, which is proof of the presence of an abrasion mechanism. These lines are usually caused by the presence of hard particles that plough into the pin. The movement of these particles over the surface causes the removal of the material along its path on the surface. Embedded particles in the worn surface can be observed in some cases (Figure $4 \mathrm{~b}$ ). In some conditions, the loss of the surface material was observed due to the delamination mechanism. Abrasion and the delamination wear mechanism predominate for a $200 \mathrm{~m}$ sliding distance, but the abrasion wear mechanism is also present in nearly all of the conditions tested mixed with other wear mechanisms. For higher sliding distances, the oxidative wear mechanism's importance increases. In all of the samples, there was evidence of oxidation, as the EDX peak of oxygen appeared for every sample.

The SEM micrographs of the cross-section worn surfaces shown in Figure 5a show the different wear mechanisms compared to the sliding distance and the analyzed material.

In the uncoated ZE41, as the sliding distance increases, the formation of a continuous oxidative wear product layer can be observed.

In the $\mathrm{Al12} \mathrm{Si} / \mathrm{SiC}$ coating, $\mathrm{SiC}$ particle detachment was not observed, but $\mathrm{Al}_{4} \mathrm{C}_{3}$ could be crack starting points. Cracks perpendicular to the sliding direction can be observed. During the wear process, subsurface cracks grow and are aroused as cracks perpendicular to the sliding direction, causing the detachment of sheet-like fragments of the worn material and producing delamination. The cracks increase with the sliding distance and form a crackle layer formed by small particles, which produces an abrasive wear mechanism and an oxidation mechanism. 

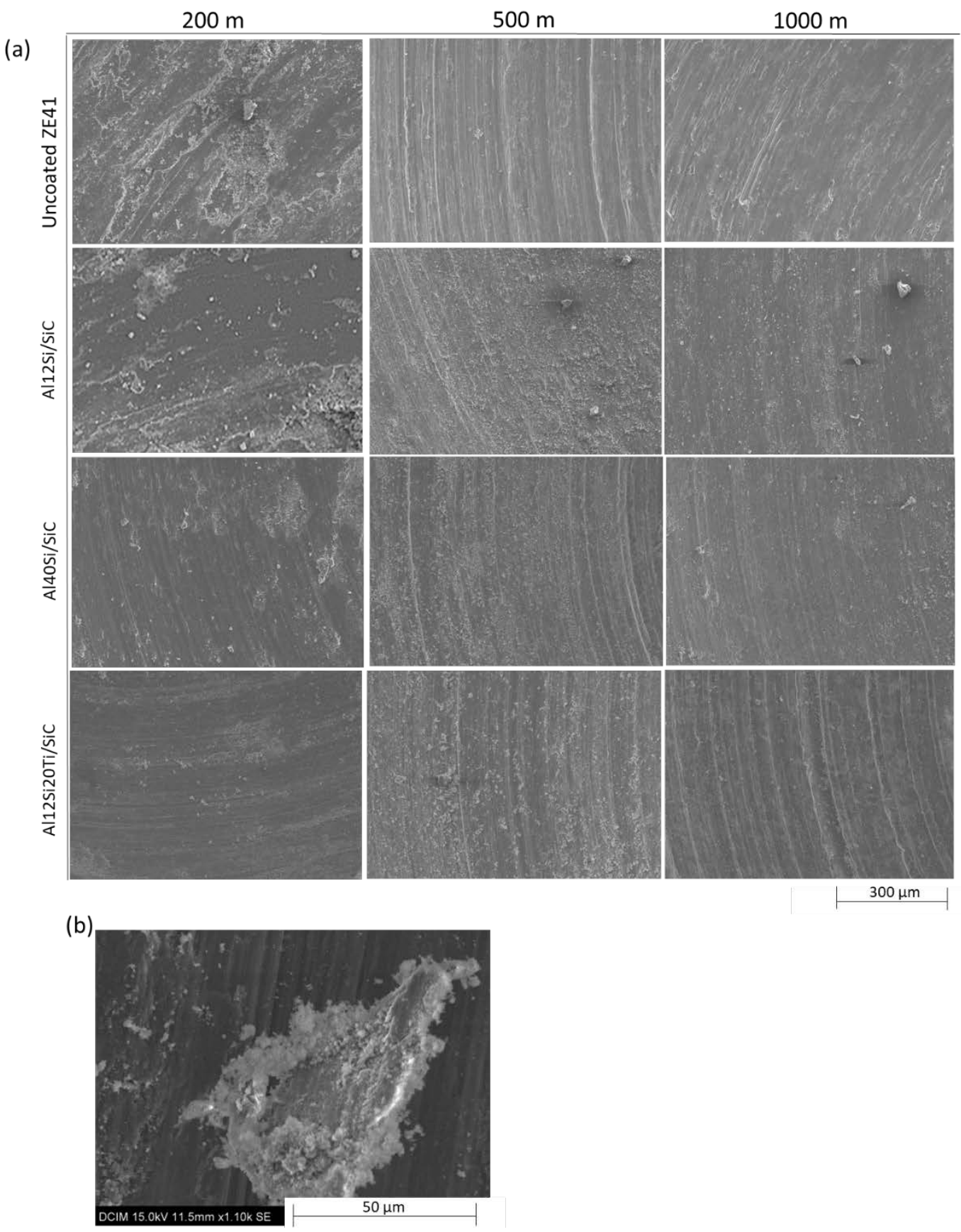

Figure 4. (a) SEM micrographs of the worn surfaces of the uncoated ZE41 and the different coatings (Al12Si/SiC, Al40Si/SiC, and Al12Si20Ti/SiC) with the sliding distance $(200 \mathrm{~m}, 500 \mathrm{~m}$, and $1000 \mathrm{~m})$; (b) detail of the worn Al12Si20Ti/SiC surface.

In the $\mathrm{Al} 40 \mathrm{Si} / \mathrm{SiC}$ coating, for a $200 \mathrm{~m}$ sliding distance, the wear mechanisms are mainly abrasion and delamination, as in the case of Al12Si/SiC, in which there were cracks perpendicular to the surface that can produce a delamination wear mechanism. $\mathrm{Mg}_{2} \mathrm{Si}$ could act as starting crack point. For higher sliding distances, an oxidative wear product layer on the wear surface can be observed, which indicates the increases of the oxidative wear mechanism.

In the Al12Si20Ti/SiC coating, for a $200 \mathrm{~m}$ sliding distance, the wear mechanism is mainly abrasive. In contrast with the other coatings, cracks were not observed in the cross-section. As in the other cases, for higher sliding distances, the oxidative mechanism increases, and an oxidative product layer on the wear surface can be observed. 


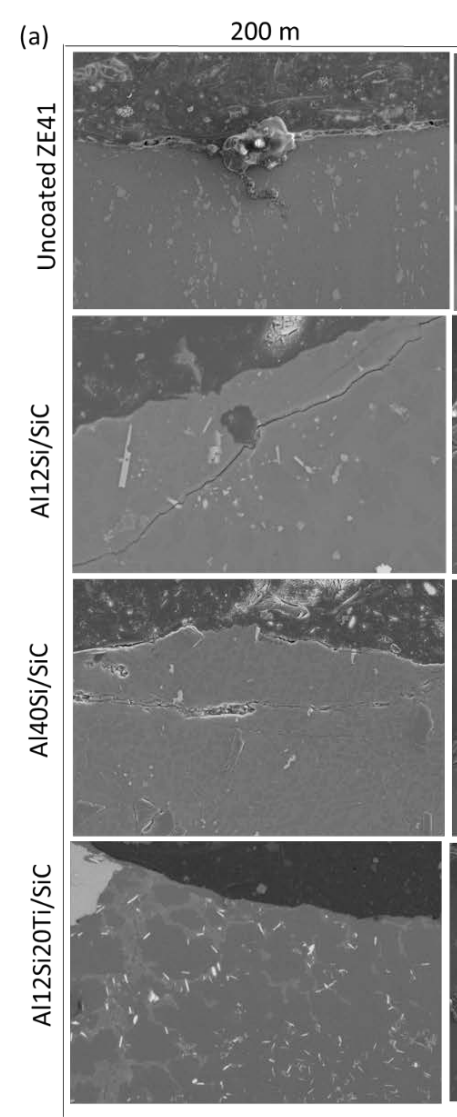

(b)

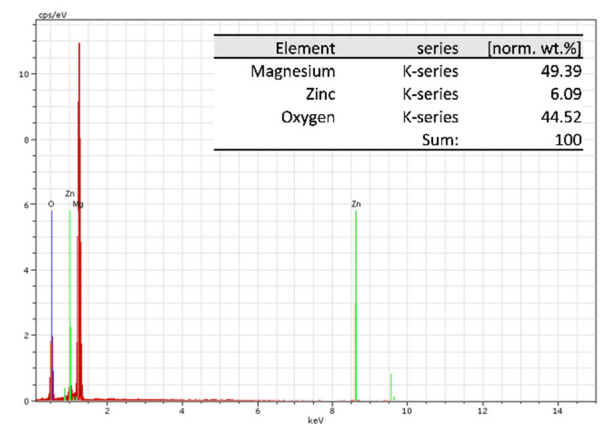

(d)

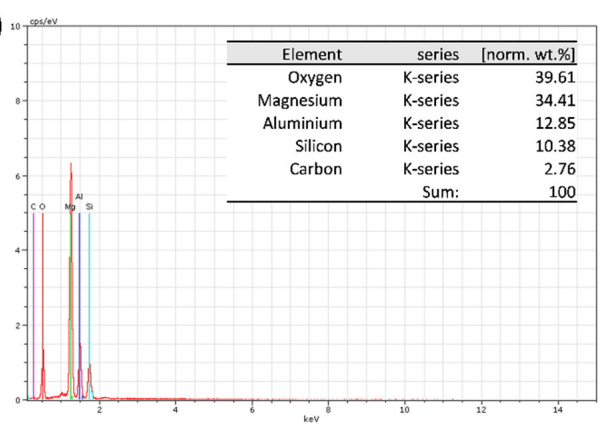

$500 \mathrm{~m}$

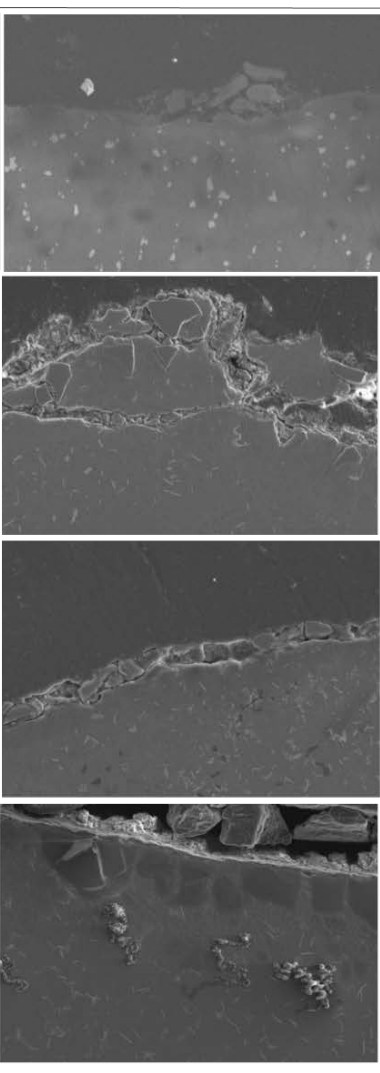

(c)

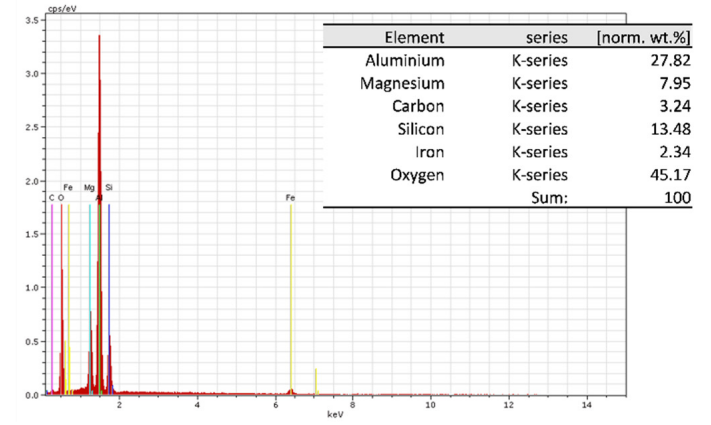

(e)

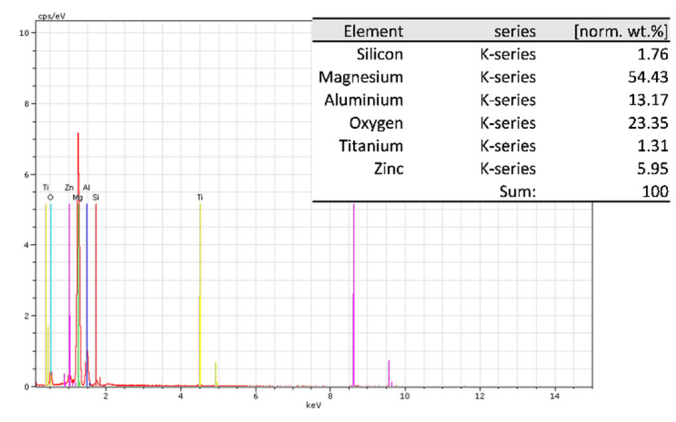

Figure 5. (a) SEM micrographs of the cross-section of the wear surface of the uncoated ZE41 and the different coatings (Al12Si/SiC, Al40Si/SiC, and Al12Si20Ti/SiC) compared to the sliding distance (200 m, $500 \mathrm{~m}$, and $1000 \mathrm{~m})$; (b) EDX analysis of the uncoated ZE41 worn surface; (c) EDX analysis of the Al12Si/SiC worn surface; (d) EDX analysis of the $\mathrm{Al} 40 \mathrm{Si} / \mathrm{SiC}$ worn surface; (e) EDX analysis of the Al12Si20Ti/SiC worn surface.

Figure 5b-f shows the EDX analysis performed on the uncoated ZE41, Al12Si/SiC, Al40Si/SiC and Al12Si-Ti/SiC coatings' worn surfaces, respectively. There was evidence of oxidation, as the EDX peak of oxygen appeared for every sample. In addition, an Fe 
peak from the pin can be observed in the Al12Si/SiC EDX analysis. In the case of the Al12Si-Ti/SiC coatings, an oxygen peak can be detected in addition to a titanium peak.

Figure 6 shows the debris obtained in the wear tests. For a $200 \mathrm{~m}$ sliding distance, in the case of uncoated ZE41, the debris is formed by $100 \mu \mathrm{m}$ short wires. In the case of the $\mathrm{Al} 12 \mathrm{Si} / \mathrm{SiC}$ and Al12Si20Ti/SiC coatings, the debris is formed by $100 \mu \mathrm{m}$ platelets. This debris presents an oxidized surface. In addition, in the case of Al40Si/SiC, the debris is constituted of $130 \mu \mathrm{m}$ particles. In all cases, the debris size decreases as the sliding distance increases. The oxidized debris particles break during the wear test and form debris agglomerates that increase the abrasive and oxidation wear mechanisms.

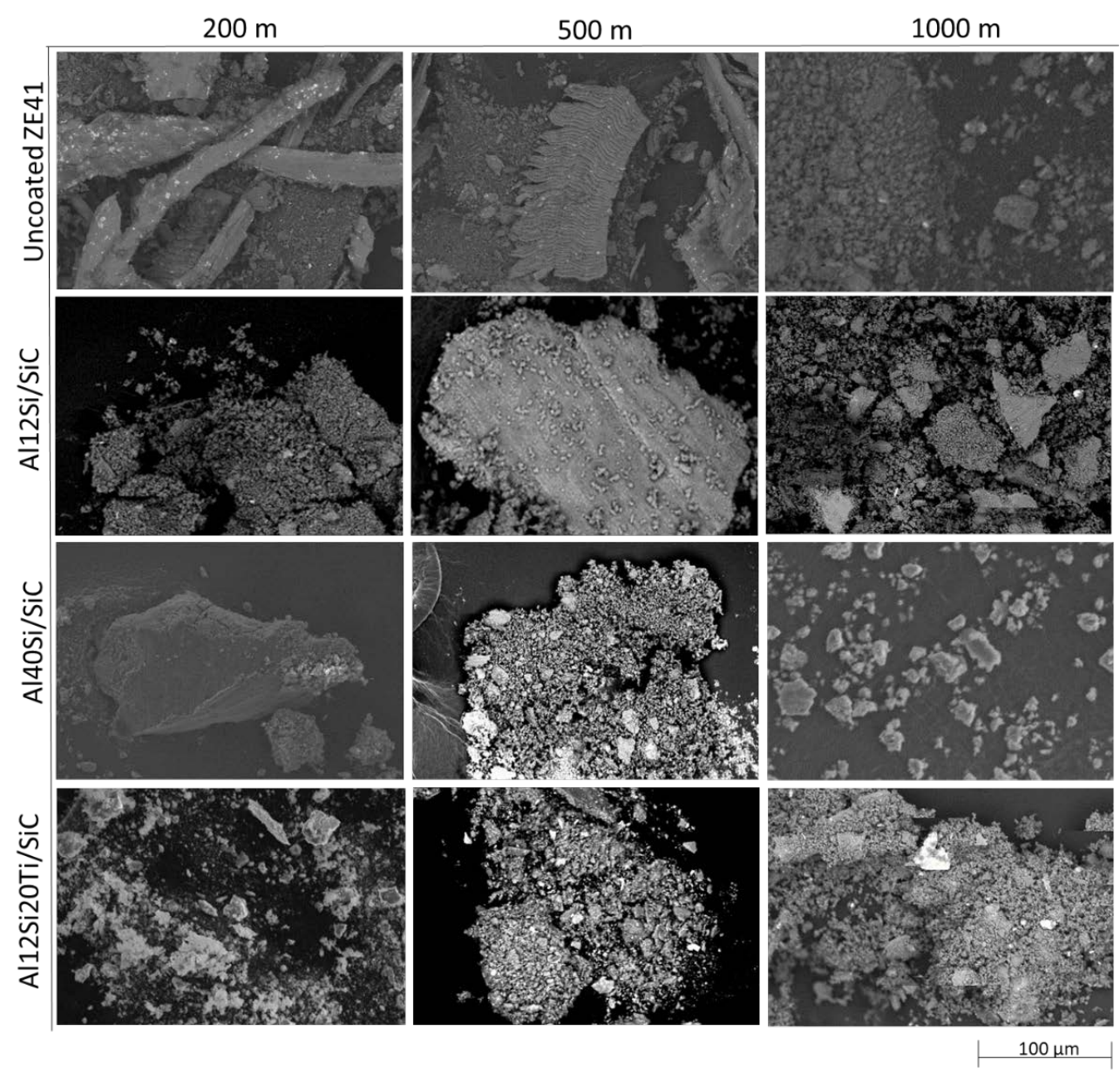

Figure 6. SEM micrographs of the debris obtained in the wear tests of the uncoated ZE41 and the different coatings (Al12Si/SiC, Al40Si/SiC, and Al12Si20Ti/SiC) compared to the sliding distance (200 m, $500 \mathrm{~m}$, and $1000 \mathrm{~m})$.

\subsection{Corrosion Products and the Corrosion Mechanism}

Figure 7 shows the corrosion properties for Al12Si/SiC, Al40Si/SiC, Al12Si-Ti/SiC coatings, and uncoated ZE41 in a $3.5 \% \mathrm{NaCl}$ solution for different immersion times $(1,24$, 96, and $168 \mathrm{~h}$ ).

The open-circuit potential (OCP) variations for the uncoated substrates and $\mathrm{Al} / \mathrm{SiC}$ coatings are represented as a function of the immersion time in the aggressive solution (Figure 7a). Two main groups of materials can be discerned by their different behaviors. The first one consists of the uncoated ZE41 magnesium alloy, and the second group consists of the composite coatings. Uncoated ZE41 showed 5\% lower $E_{\text {corr }}$ values than any of the coated systems. In this sample, $E_{\text {corr }}$ gradually increased until $50 \mathrm{~h}$, and for the lower immersion times the $E_{\text {corr }}$ remained constant. 


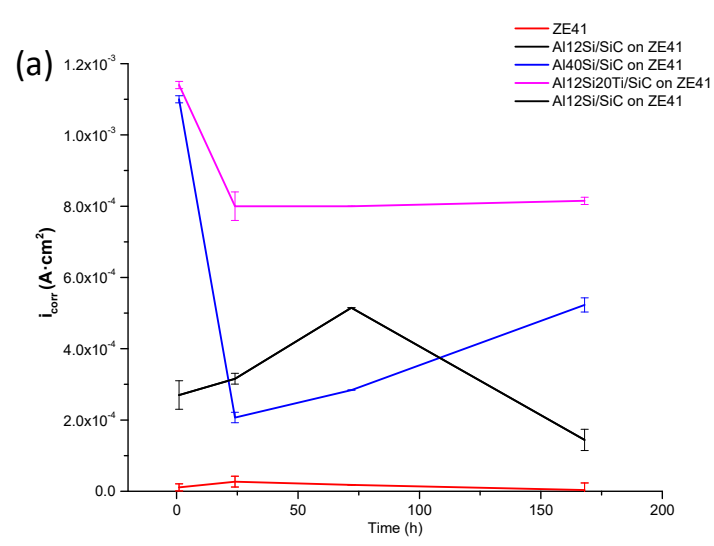

(b)

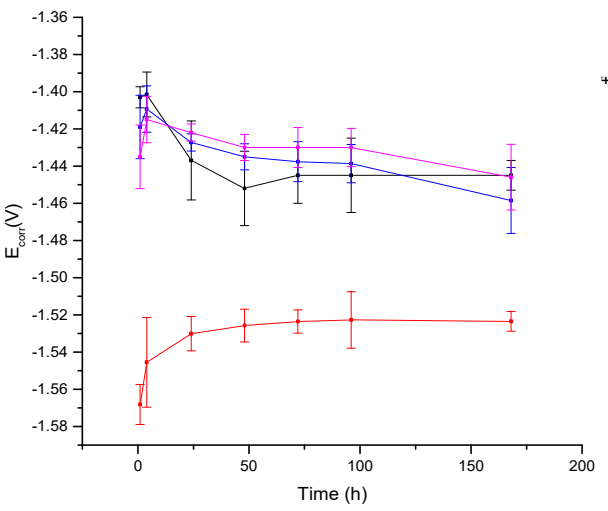

(c)

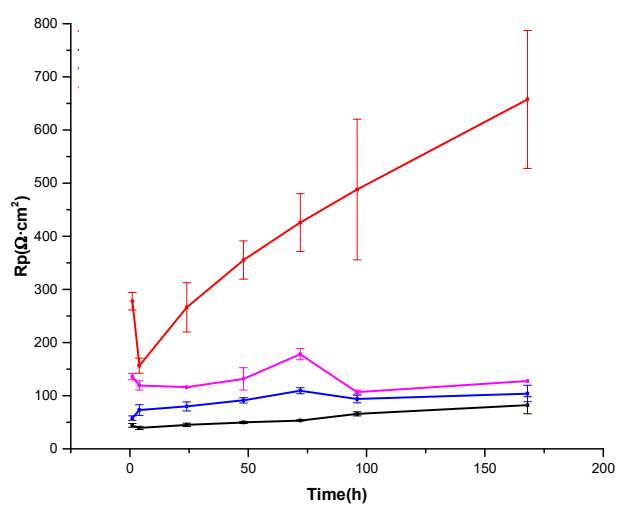

(d)

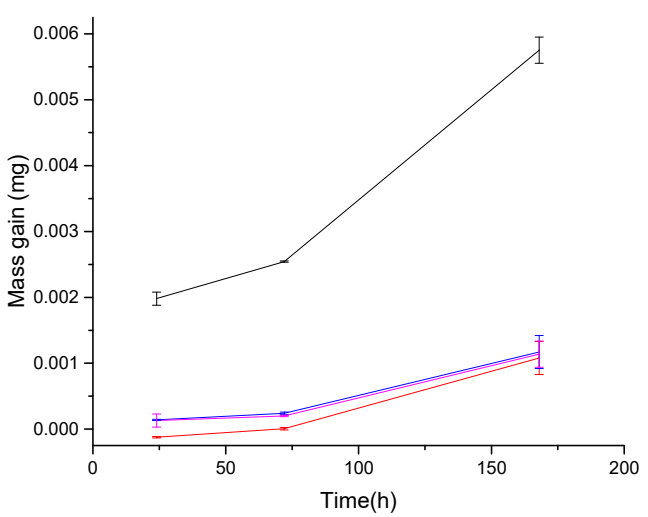

Figure 7. Corrosion properties for the Al12Si/SiC, Al40Si/SiC, and Al12Si-Ti/SiC coatings and uncoated ZE41 in a $3.5 \%$ $\mathrm{NaCl}$ solution: (a) OCP measurement vs. immersion time; (b) current density $\left(\mathrm{A} \cdot \mathrm{cm}^{2}\right)$ behavior vs. immersion time; (c) Polarization resistance $\left(R_{p}\right)$ vs. immersion time; $(\mathbf{d})$ mass gain vs. immersion time.

In all of the coated systems, $E_{c o r r}$ increases for the first hour of immersion, followed by a decrease before the first $48 \mathrm{~h}$.

For low immersion times, the $\mathrm{Al} 12 \mathrm{Si} / \mathrm{SiC}$ coatings' $E_{\text {corr }}$ remained constant. However, the $\mathrm{Al} 40 \mathrm{Si} / \mathrm{SiC}$ and Al12Si20Ti/SiC coatings gradually decrease. In all cases, the $E_{\text {corr }}$ after $168 \mathrm{~h}$ was similar, and they were more active than the ZE41 substrate.

The corrosion current flows at OCP were measured under potentiostatically controlled conditions. Figure $7 \mathrm{~b}$ shows the variation of the corrosion current density with the time for the uncoated and $\mathrm{Al} / \mathrm{SiC}$ coatings.

The uncoated substrate has a lower current density than the coated ones. In the first $24 \mathrm{~h}$, an increase of the current density can be observed following a decrease of this factor, indicating the protective oxide layer's formation.

At the start of the experiment, $\mathrm{Al} 2 \mathrm{Si} / \mathrm{SiC}$ had a higher current density than the uncoated ZE41, but lower than the other coated systems. The Al12Si/SiC current density gradually increased for the first $75 \mathrm{~h}$, indicating the occurrence of a rapid anodic reaction; however, for lower immersion times, the current density decreases due to the protective oxide layer's formation. $\mathrm{Al} 40 \mathrm{Si} / \mathrm{SiC}$ and $\mathrm{Al} 12 \mathrm{Si}-\mathrm{Ti} / \mathrm{SiC}$ coatings have the highest current density; however, for the first $24 \mathrm{~h}$, they follow a similar behavior: the current density decreases due to the protective layer's formation. However, for higher immersion times, their behavior changes as a function of their composition. The Al12Si-Ti/SiC coating current density remains constant for all of the time, but at higher values than other systems. On the other hand, from $24 \mathrm{~h}$ to $96 \mathrm{~h}$, the $\mathrm{Al} 40 \mathrm{Si} / \mathrm{SiC}$ current density is lower than the other coatings, but the current density increases quickly with time, indicating the occurrence of a rapid anodic reaction.

The corrosion behavior of the uncoated substrate and $\mathrm{Al} / \mathrm{SiC}$ coatings was also studied in terms of the evolution of the polarization resistance $\left(R_{p}\right)$ with the immersion time (Figure 7c). Uncoated ZE41 Rp gradually increases after $24 \mathrm{~h}$ immersion due to the 
superficial oxide protective layer's formation. The coated systems follow similar behaviors, but the increase is $85 \%$ lower than the uncoated sample and, in some cases, the $R_{p}$ value decreases due to the breaking of the protective superficial layer. The noblest coating is $\mathrm{Al12Si-Ti/SiC,} \mathrm{followed} \mathrm{by} \mathrm{Al40Si/SiC.}$

Figure $7 \mathrm{~d}$ shows the mass gain evolution $(\mathrm{mg})$ with the immersion time. In all cases, from $75 \mathrm{~h}$, the mass gain increases. The $\mathrm{Al} 12 \mathrm{Si} / \mathrm{SiC}$ coating shows the highest mass gain ( $81 \%$ higher than the other samples). The other samples show much lower mass gain, and it is similar in all of them.

\subsection{Corrosion Products and the Corrosion Mechanism}

The uncoated and coated samples were analyzed by SEM and EDS in order to identify the morphology and composition of the corrosion products when the materials were immersed in $3.5 \mathrm{wt} . \% \mathrm{NaCl}$ at $25{ }^{\circ} \mathrm{C}$ for $168 \mathrm{~h}$. The corrosion attack occurred in different ways in the different systems.

The surface morphology of the uncoated ZE41 immersed in the test solution for $168 \mathrm{~h}$ is shown in Figure 8a. Figure $8 \mathrm{~b}$ shows a detail of the acicular morphology of the corrosion products formed. Figure $8 \mathrm{c}$ shows a cross-section of the specimen. We can observe a detail of the layer cross-section in the Figure $8 \mathrm{c}$ inset. The uncoated ZE41 surface presents generalized corrosion. The continuous oxidation product layer is $10 \mu \mathrm{m}$ in the thinnest zone and $30 \mu \mathrm{m}$ in the thickest zone. However, in some zones, the surface presented localized attacks. In these zones, there were signs of the nucleation and growth of a new layer of oxidized products. We can observe the accumulation of corrosion products on the coating surface. The formation of a protective superficial oxide layer produces the $E_{c o r r}$ constant after the first $50 \mathrm{~h}$ immersed, as can be observed in Figure 7a. The EDS (Figure 8d) formed on the surface shown in Figure 8a reveals that the corrosion products are formed mainly of $\mathrm{O}$ and $\mathrm{Mg}$.
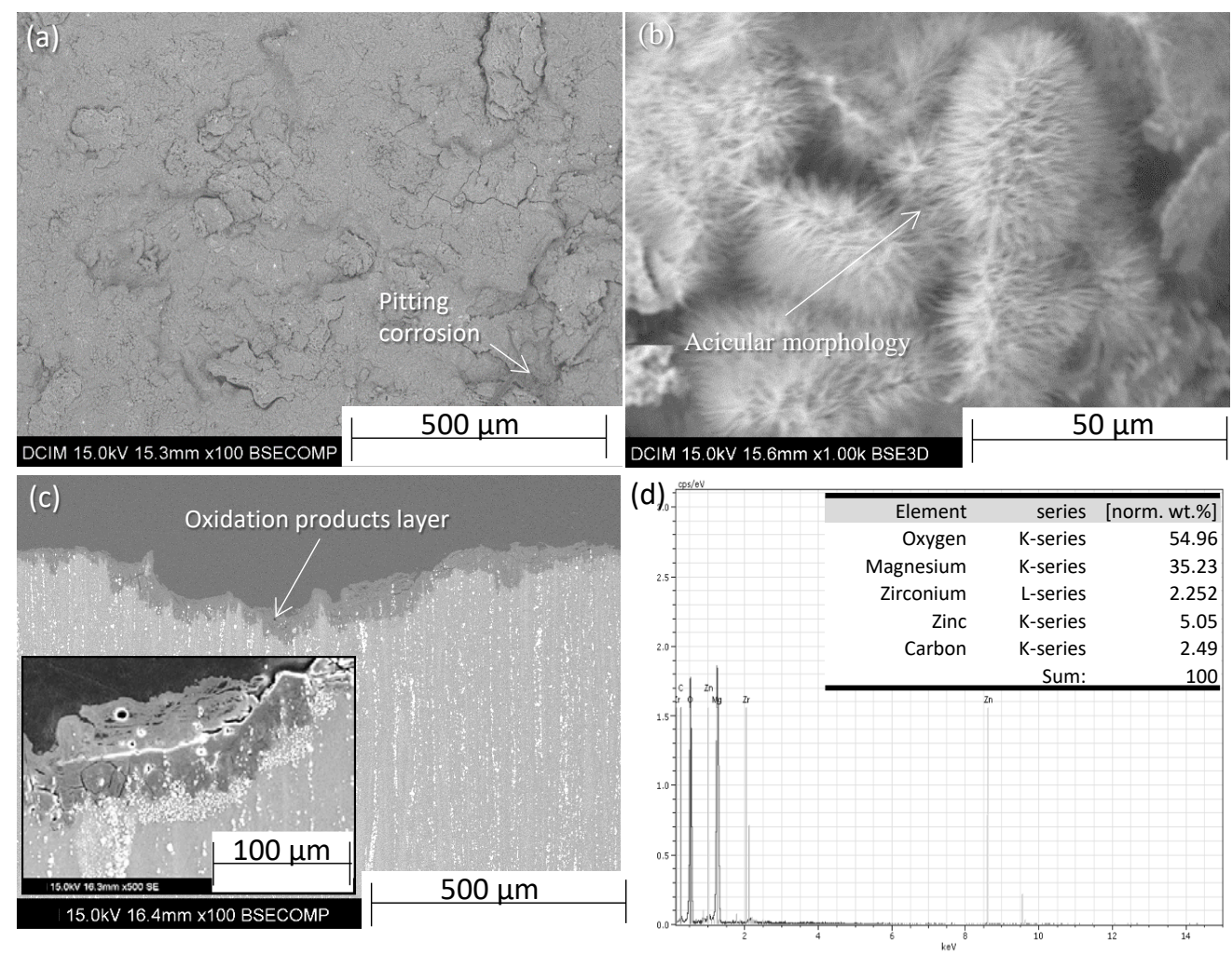

Figure 8. SEM surface morphology of the uncoated ZE41 surface after $168 \mathrm{~h}$ of immersion in $3.5 \mathrm{wt} . \%$ $\mathrm{NaCl}$ : (a) general view; (b) detail of the acicular corrosion products of (a); (c) cross-section; inset: detail of the oxidation product layer; (d) EDS analysis (of the surface shown in (a). 
The Al12Si/SiC coating corrosion surface is shown in Figure 9a. As is the case of the uncoated ZE41, an oxidation product layer was observed. In this case, the oxidation product layer is thicker (between $100 \mu \mathrm{m}$ and $150 \mu \mathrm{m}$ ). In addition, the surface presented pitting corrosion and a cracked surface. Figure $9 \mathrm{~b}$ shows a detail of the acicular corrosion products formed that are similar to the corrosion products formed on the ZE41 sample.
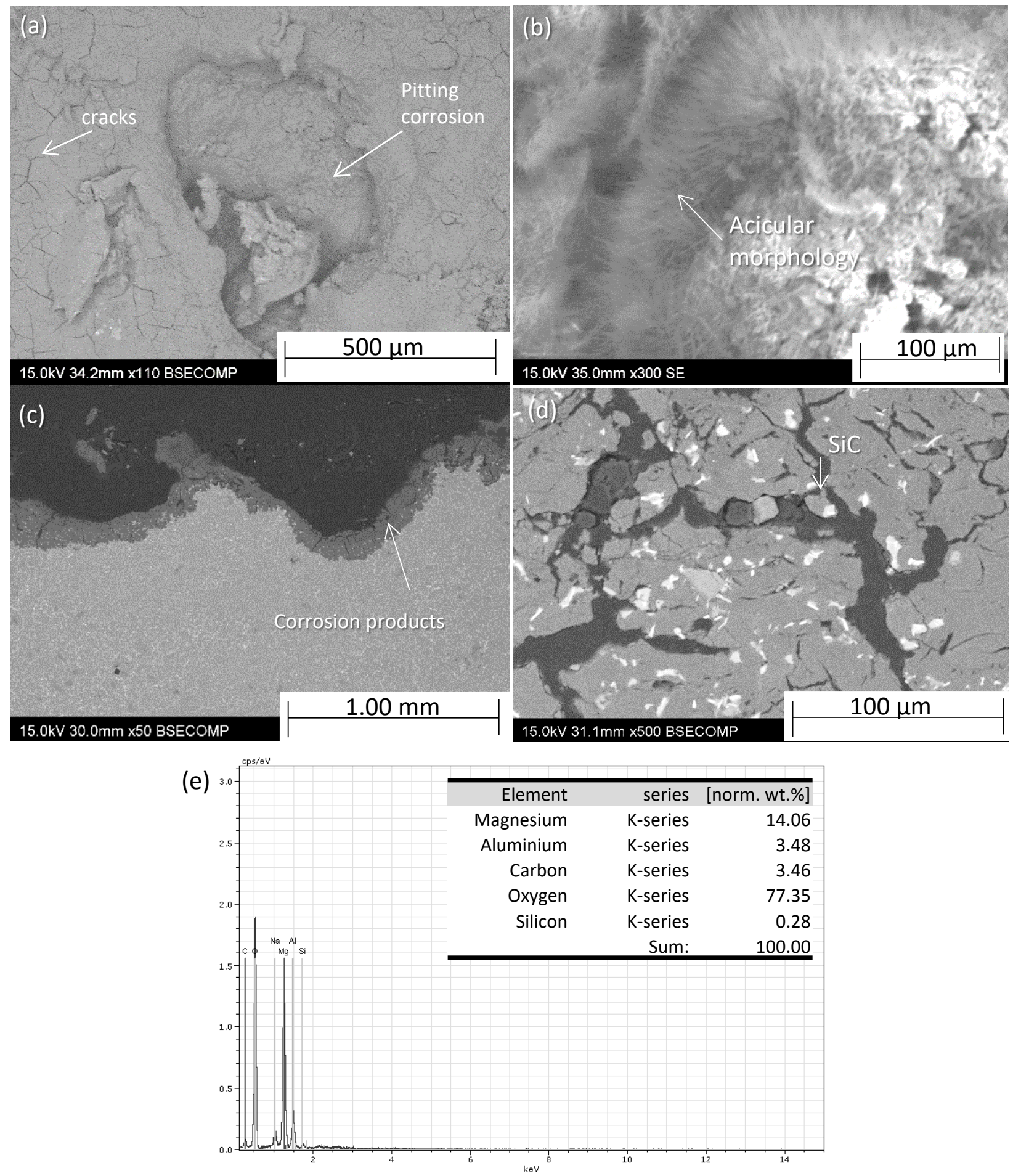

Figure 9. SEM surface morphology of the Al12Si/SiC coating surface after $168 \mathrm{~h}$ of immersion in $3.5 \mathrm{wt} \% \mathrm{NaCl}$ : (a) general view; (b) detail of the acicular corrosion products of (a); (c) cross-section; (d) detail of the oxidation product layer of (c); (e) EDS analysis of the surface shown in (a). 
Figure $9 \mathrm{c}$ shows a cross-section of the specimen, and a detail of this zone is shown inset. We can observe that the corrosion progresses along the interdendritic micro-constituent.

Figure 10a shows the Al40Si/SiC corrosion surface. As in the other cases, there is an acicular oxidation product layer. In some zones, this layer was cracked and pitting corrosion was observed (Figure 10b). Figure 10c shows an SiC particle partially covered by the oxidation product layer. The cross-section of the sample is shown in Figure 10c. The oxidation layer is thicker than in the other cases (around $200 \mu \mathrm{m}$ ) (Figure 10c inset). In addition, pitting corrosion is observed in the coating-substrate interface (Figure 10c). The pitting corrosion occurred from the contact between the primary Si particles and the matrix. The EDS (Figure 10e) shows that the corrosion products are formed mainly by Al, $\mathrm{Mg}$ and $\mathrm{O}$.
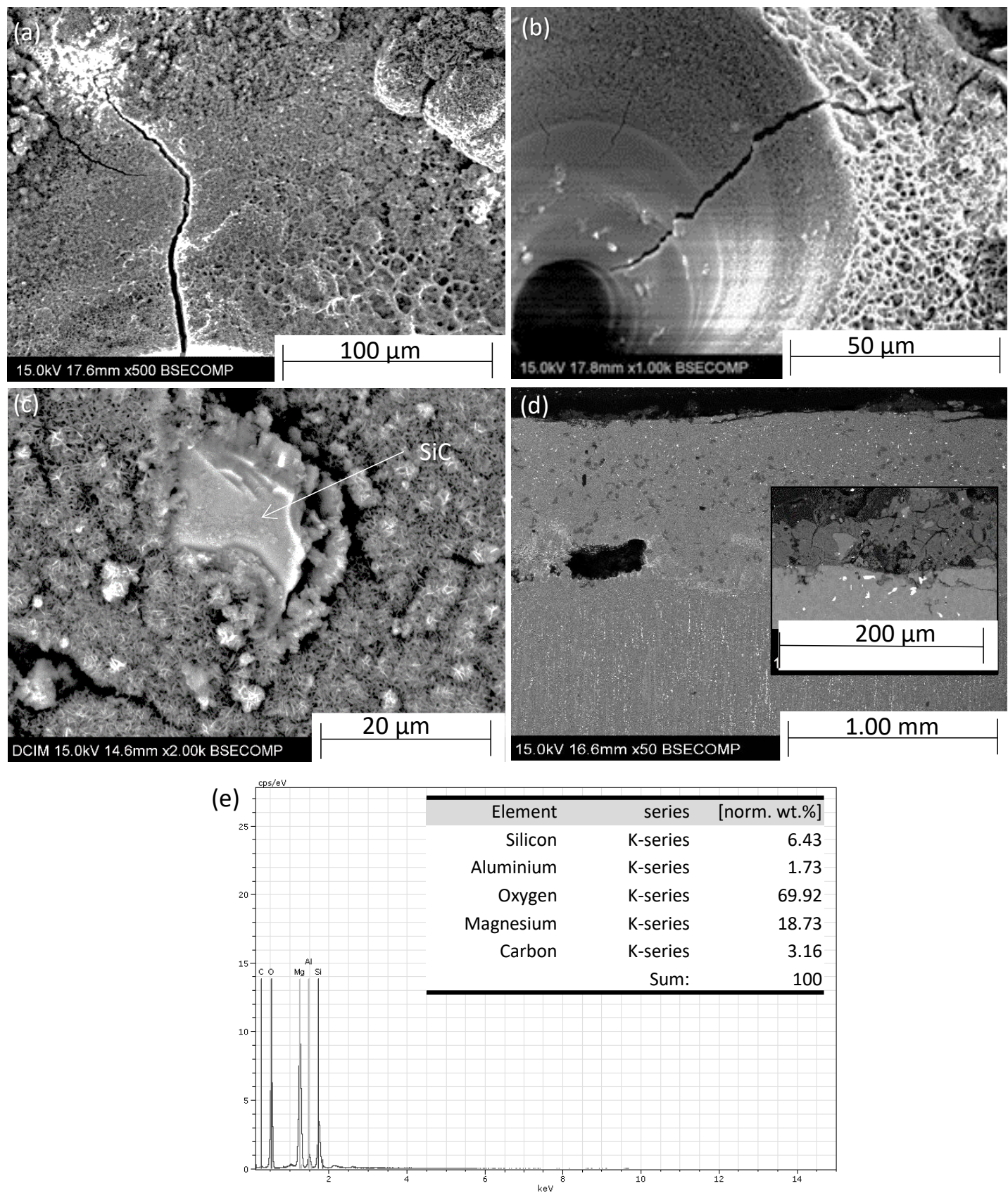

Figure 10. SEM surface morphology of the Al40Si/SiC coating's surface after $168 \mathrm{~h}$ of immersion in $3.5 \mathrm{wt} . \% \mathrm{NaCl}$ : (a) general view; (b) detail; (c) detail of the acicular corrosion products of (a); (d) cross-section, (inset) detail of the cross-section's surface; (e) EDS analysis of the surface shown in (a). 
The Al12Si-Ti/SiC surface (Figure 11a) presents the same corrosion product layer but in this case, the layer is less continuous than in the others as shown in Figure 11b, where the cross-section of the sample can be observed. The oxidation product layer thickness varies from $1 \mathrm{~mm}$ to uncoated zones. The corrosion products are acicular, with a shape that is similar to the other products observed before (inset Figure 11a). Figure 12c shows that the corrosion product layer progressed between the Ti-rich zones ( $\mathrm{TiSi}_{2}, \mathrm{TiAl}_{3}$, and $\mathrm{TiC}$ ), as evidenced by the cracks formed because of the pitting in the vicinity of Ti. Therefore, it seems that, in these zones, micro-galvanic couples were formed. The EDS (Figure 10e) shows that the corrosion products are formed mainly by $\mathrm{Al}$ and $\mathrm{O}$.
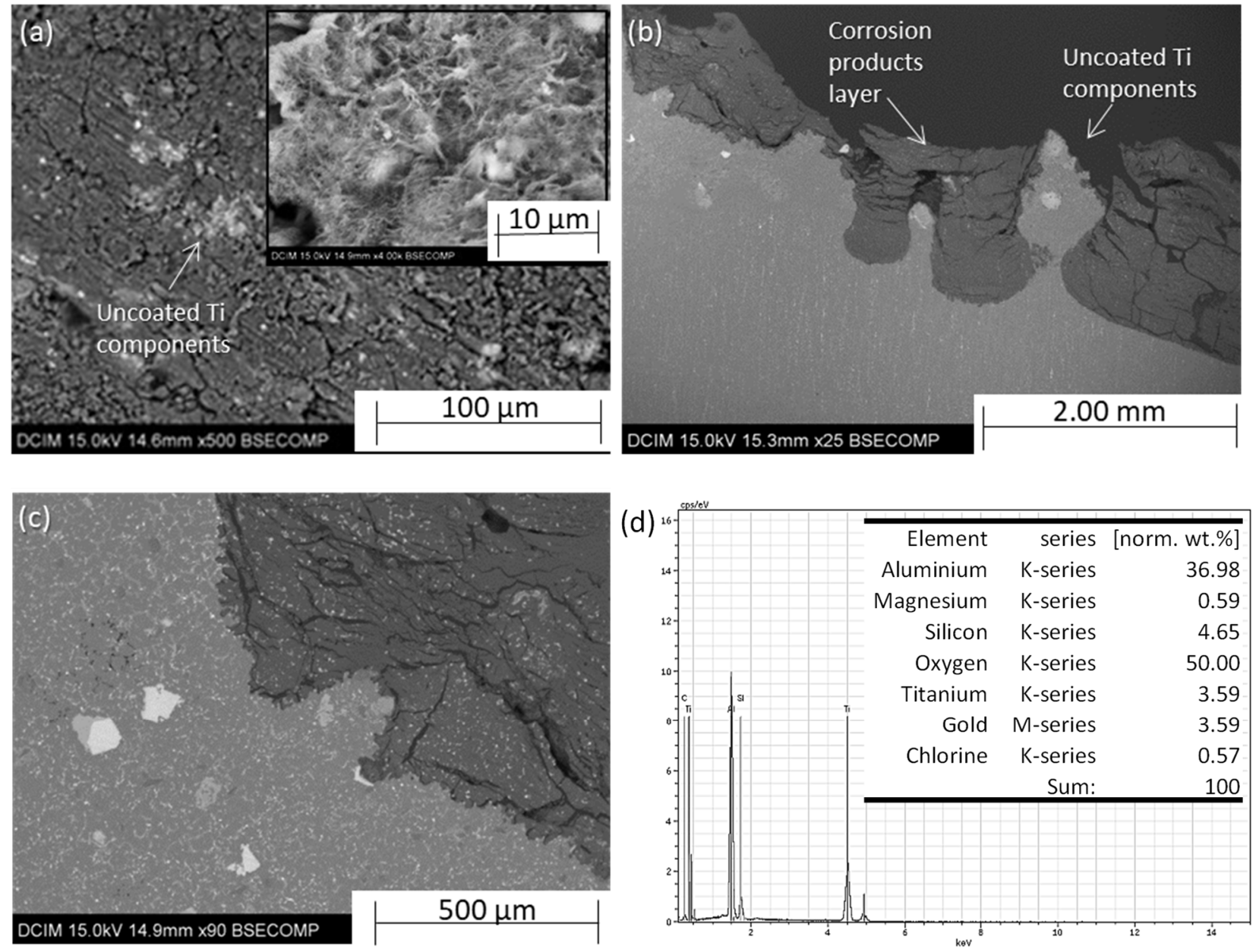

Figure 11. SEM surface morphology of the Al12Si-Ti/SiC coating's surface after $168 \mathrm{~h}$ of immersion in $3.5 \mathrm{wt} \% \mathrm{NaCl}$ : (a) general view; inset, detail; (b) cross-section; (c) detail of (b); (d) EDS analysis of the surface shown in (a).

In all of the coated systems, the formation and subsequent breaking of the superficial oxide layer means that the $E_{\text {corr }}$ increases for the first immersion hour, followed by a decrease for the first $48 \mathrm{~h}$, as can be observed in Figure $7 \mathrm{a}$. 
(a)

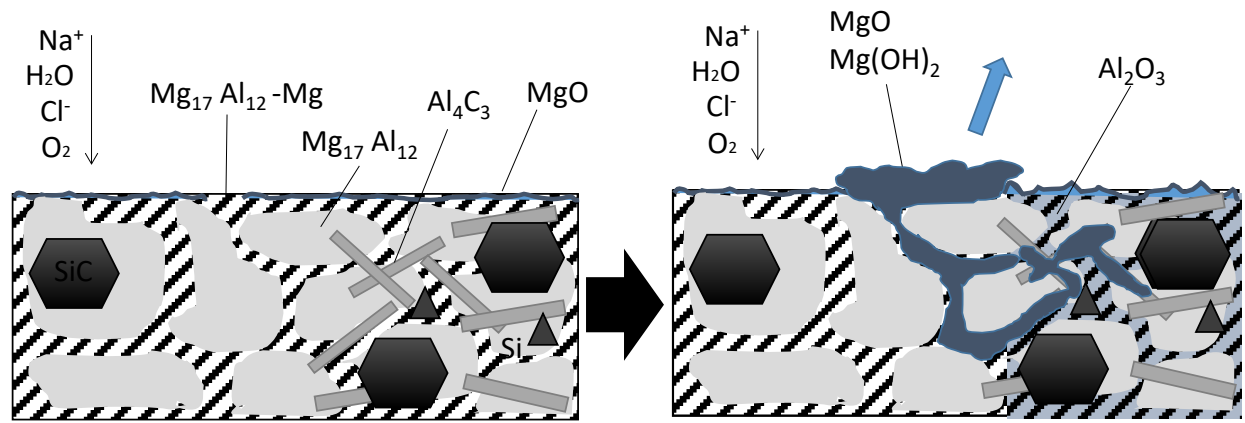

(b)

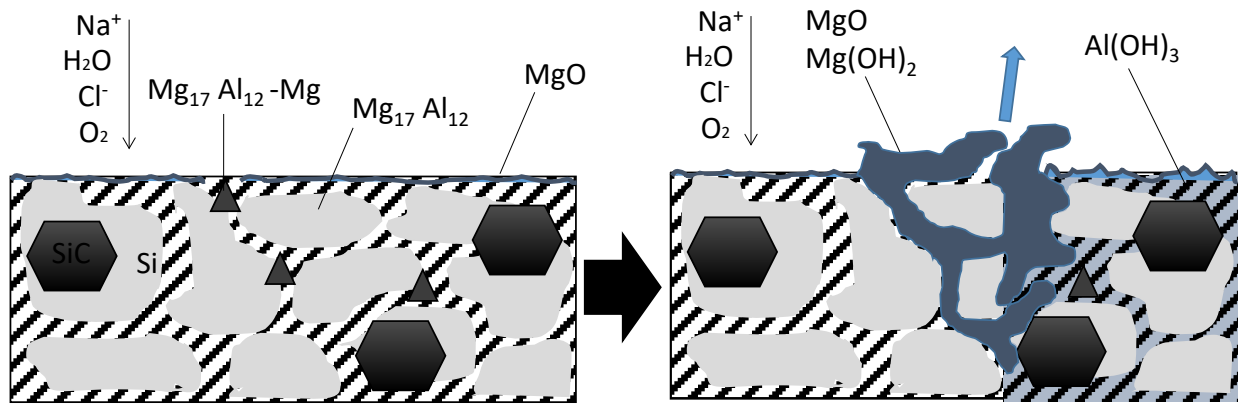

(c)
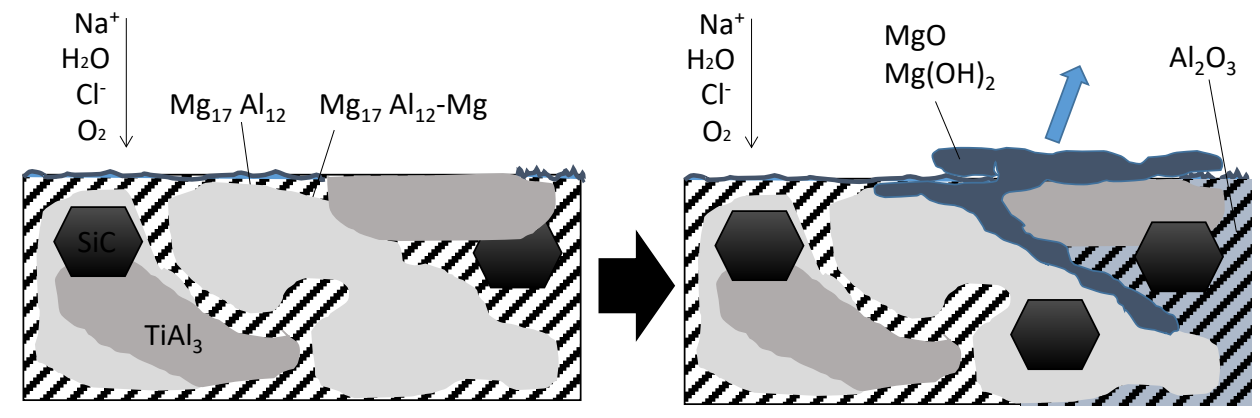

Figure 12. Corrosion mechanism scheme: (a) Al12Si/SiC coating surface; (b) Al40Si/SiC coating surface; (c) Al12Si20Ti/SiC coating surface.

Figure 12 shows the different corrosion mechanisms of the coatings. The corrosive attack on the Al12Si/SiC surface (Figure 12a) occurs principally through the MgO surface layer discontinuities due to the presence of $\mathrm{SiC}$ and intermetallics. Additionally, pitting corrosion occurs in the interface between $\mathrm{Al}_{12} \mathrm{Mg}_{17}-\mathrm{Mg}$. The $\mathrm{Al}_{12} \mathrm{Mg}_{17}-\mathrm{Mg}$ dissolution takes place following the reactions (1) and (2):

$$
\begin{gathered}
\mathrm{Mg}(\mathrm{s}) \rightarrow \mathrm{Mg}^{2+}(\mathrm{aq})+2 \mathrm{e}^{-} \text {(anodic reaction) } \\
2 \mathrm{H}_{2} \mathrm{O}+2 \mathrm{e}^{-} \rightarrow \mathrm{H}_{2}+2 \mathrm{OH}^{-}(\mathrm{aq}) \text { (cathodic reaction) } \\
\mathrm{Mg}^{2+}+2 \mathrm{OH}^{-}(\mathrm{aq}) \rightleftarrows \mathrm{Mg}(\mathrm{OH})_{2}
\end{gathered}
$$

Then, the $\mathrm{Mg}(\mathrm{OH})_{2}$ layer is degraded by the following reaction.

At the same time, $\mathrm{Al}_{2} \mathrm{O}_{3}$ is formed in the interface of $\mathrm{Al}_{12} \mathrm{Mg}_{17}-\mathrm{Mg}$ and $\mathrm{Al}_{12} \mathrm{Mg}_{17}$. The main reactions that take place are the following:

$$
\begin{gathered}
\mathrm{Al}^{3+}+3 \mathrm{H}_{2} \mathrm{O} \rightleftarrows \mathrm{Al}(\mathrm{OH})_{3}+3 \mathrm{H}^{+} \\
\mathrm{Al}^{3+}+2 \mathrm{H}_{2} \mathrm{O} \rightleftarrows \mathrm{AlO}(\mathrm{OH})+3 \mathrm{H}^{+} \\
\mathrm{Al}_{2} \mathrm{O}_{3}+2 \mathrm{nCl}^{-}+6 \mathrm{H}^{+} \rightleftarrows 2 \mathrm{AlCl}_{\mathrm{n}}{ }^{(3-\mathrm{n})+}+3 \mathrm{H}_{2} \mathrm{O}
\end{gathered}
$$

When these oxides surround an $\mathrm{Al}_{12} \mathrm{Mg}_{17}-\mathrm{Mg}$ eutectic or a $\mathrm{Mg}_{2}$ Si dendrite, $\mathrm{Mg}(\mathrm{OH})_{2}$ is formed around the adjoining dendrites, causing a massive material detachment. 
The Al40Si/SiC corrosion mechanism is shown in Figure 12b. SiC particles act as pitting zones, because in these zones there are discontinuities on the corrosion product layer. In these coatings, $\mathrm{Al}_{4} \mathrm{C}_{3}$ needles were not observed; for this reason, there are fewer zones for the easy advance. The main reactions that take place are the same as those in the $\mathrm{Al12Si} / \mathrm{SiC}$ coating.

Figure 12c shows the Al12Si20Ti/SiC corrosion mechanism. The oxide surface layer does not cover all of the coating's surface (the $\mathrm{TiSi}_{2}, \mathrm{TiAl}_{3}$, and $\mathrm{TiC}$ are zones of discontinuities on the oxide product layer). The attack occurs through the surface discontinuities ( $\mathrm{TiSi}_{2}$, $\mathrm{TiAl}_{3}$, and $\mathrm{TiC}$ ). $\mathrm{Cl}^{-}$ions, because of their small size, enter through the matrix interface and form galvanic microcells with the aluminum, and act as the start of pitting points.

\section{Conclusions}

$\mathrm{Al} / \mathrm{SiC}$ composite coatings on ZE41 magnesium alloy have $40 \%$ lower wear rates than the substrate. The differences between the coatings are caused by changes in the microstructure. The absence of $\mathrm{Al}_{4} \mathrm{C}_{3}$ in the Al40Si/SiC and Al12Si20Ti/SiC coatings' microstructures produce a higher matrix-reinforcement interface resistance and a lower wear rate $(11 \%$ and $7 \%$ lower, respectively, in comparison with the Al12Si/SiC coating). The microstructure impacts on the microhardness and the friction coefficient. The microhardness increases more than $\times 3.5$ in all of the coatings. The Al12Si $/ \mathrm{SiC}$ friction coefficient is $27 \%$ higher than the uncoated ZE41, due to the presence of hard $\mathrm{Al}_{4} \mathrm{C}_{3}$. In the $\mathrm{Al} 40 \mathrm{Si} / \mathrm{SiC}$ coatings, the friction coefficient is 18\% higher than that in the ZE41 substrate due to the higher amount of primary silicon phases. In the Al12Si20Ti/SiC coatings, the friction coefficient is similar to the uncoated ZE41 because the phases formed have a small size. The wear mechanisms depend on the composition.

Uncoated ZE41 showed 5\% lower Ecorr values than any of the coated systems. The coated systems have a similar Rp value, but it is $85 \%$ lower than that in the uncoated sample. However, the inhibition of the formation of $\mathrm{Al}_{4} \mathrm{C}_{3}$, by the addition of $\mathrm{Si}$ or $\mathrm{Ti}$, improves the corrosion behavior of the coatings. In addition, the corrosion mechanisms are caused by the presence of discontinuities on the corrosion product layer formed at the surface.

The wear behaviors of the ZE41 alloys were improved, although the coating systems were more sensitive to corrosion. However, the changes in the microstructures obtained by adding the alloying elements to the powder used show that it is possible to modify it by controlling the composition of the cladding layer.

Author Contributions: Conceptualization, J.R.; P.R. and A.R.; methodology, J.R.; P.R. and M.D.E.-R.; investigation, A.R.; writing-original draft preparation, J.R.; writing-review and editing, J.R. funding acquisition, J.R.; P.R. and A.R. All authors have read and agreed to the published version of the manuscript.

Funding: The authors wish to express their gratitude to the Comunidad de Madrid (ADITIMAT-CM S2018/NMT-4411) and (ADITINANO 2020/00007/019), Universidad Rey Juan Carlos (2020/00006/004) and Agencia Estatal de Investigación (RTI2018-096391-B-C31) for the economic support.

Institutional Review Board Statement: Not applicable.

Informed Consent Statement: Not applicable.

Data Availability Statement: No new data were created or analyzed in this study. Data sharing is not applicable to this article.

Conflicts of Interest: The authors declare no conflict of interest. 


\section{References}

1. Dubourg, L.; Ursescu, D.; Hlawka, F.; Cornet, A. Laser cladding of MMC coatings on aluminium substrate: Influence of composition and microstructure on mechanical properties. Wear 2005, 258, 1745-1754. [CrossRef]

2. Bodunrin, M.O.; Alaneme, K.K.; Chown, L.H. Aluminium matrix hybrid composites: A review of reinforcement philosophies; mechanical, corrosion and tribological characteristics. J. Mater. Res. Technol. 2015, 4, 434-445. [CrossRef]

3. Gupta, M.; Gupta, N. The Promise of Magnesium Based Materials in Aerospace Sector History and Current Trends of Magnesium in Aerospace Sector. Int. J. Aeronaut. Aerosp. Res. Int. J. Aeronaut. Sci. Aerosp. Res. 2017, 4, 141-149.

4. Dieringa, H.; Hort, N.; Letzig, D.; Bohlen, J.; Höche, D.; Blawert, C.; Zheludkevich, M.; Kainer, K.U. Mg alloys: Challenges and achievements in controlling performance, and future application perspectives. In The Minerals Metals and Materials Series; Springer: Cham, Switzerland, 2018.

5. Zhang, L.; Xu, H.; Wang, Z.; Li, Q.; Wu, J. Mechanical properties and corrosion behavior of Al/SiC composites. J. Alloys Compd. 2016, 678, 23-30. [CrossRef]

6. Sulaiman, S.; Marjom, Z.; Ismail, M.I.S.; Ariffin, M.K.A.; Ashrafi, N. Effect of Modifier on Mechanical Properties of Aluminium Silicon Carbide (Al-SiC) Composites. Procedia Eng. 2017, 184, 773-777. [CrossRef]

7. Flanagan, S.; Main, J.; Lynch, P.; Vanderwiel, C.; Roth, J.T. A mechanical evaluation of an overaged aluminum metal-matrixcomposite (2009 Al/SiC/15p MMC). Procedia Manuf. 2019, 34, 58-64. [CrossRef]

8. Riquelme, A.; Rodrigo, P.; Escalera-Rodríguez, M.D.; Rams, J. Analysis and optimization of process parameters in Al-SiCp laser cladding. Opt. Lasers Eng. 2016, 78, 165-173. [CrossRef]

9. Riquelme, A.; Escalera-Rodriguez, M.D.; Rodrigo, P.; Rams, J. Role of Laser Cladding Parameters in Composite Coating (Al-SiC) on Aluminum Alloy. J. Therm. Spray Technol. 2016, 25, 1177-1191. [CrossRef]

10. Bieniaś, J.; Walczak, M.; Surowska, B.; Sobczak, J. Microstructure and corrosion behaviour of aluminum fly ash composites. J. Optoelectron. Adv. Mater. 2003, 5, 493-502.

11. Yao, J.; Zhang, J.; Wu, G.; Wang, L.; Zhang, Q.; Liu, R. Microstructure and wear resistance of laser cladded composite coatings prepared from pre-alloyed WC-NiCrMo powder with different laser spots. Opt. Laser Technol. 2018, 101, 520-530. [CrossRef]

12. Jiao, X.; Wang, C.; Gong, Z.; Wang, G.; Sun, H.; Yang, H. Effect of Ti on T15M composite coating fabricated by laser cladding technology. Surf. Coatings Technol. 2017, 325, 643-649. [CrossRef]

13. Gao, T.; Wang, D.; Du, X.; Li, D.; Liu, X. Phase transformation mechanism of Al4C3 by the diffusion of Si and a novel method for in situ synthesis of $\mathrm{SiC}$ particles in Al melt. J. Alloys Compd. 2016, 685, 91-96. [CrossRef]

14. Rams, J.; Ureña, A.; Campo, M. Dual layer silica coatings of SiC particle reinforcements in aluminium matrix composites. Surf. Coat. Technol. 2006, 200, 4017-4026. [CrossRef]

15. Ureña, A.; Escalera, M.; Gil, L. Influence of interface reactions on fracture mechanisms in TIG arc-welded aluminium matrix composites. Compos. Sci. Technol. 2000, 60, 613-622. [CrossRef]

16. Vreeling, J.A.; Ocelík, V.; Pei, Y.T.; Van Agterveld, D.T.L.; De Hosson, J.T.M. Laser melt injection in aluminum alloys: On the role of the oxide skin. Acta Mater. 2000, 48, 4225-4233. [CrossRef]

17. Anandkumar, R.; Almeida, A.; Colaco, R.; Vilar, R.; Ocelik, V.; De Hosson, J.T.M. Microstructure and wear studies of laser clad Al-Si/SiC(p) composite coatings. Surf. Coatings Technol. 2007, 201, 9497-9505. [CrossRef]

18. Han, N.; Pollard, G.; Stevens, R. Interfacial structure and fracture of aluminium alloy A356-SiC particle metal matrix composite. Mater. Sci. Technol. 1992, 8, 184-188. [CrossRef]

19. Riquelme, A.; Rodrigo, P.; Escalera-rodríguez, M.D.; Rams, J. Characterisation and mechanical properties of $\mathrm{Al} / \mathrm{SiC}$ metal matrix composite coatings formed on ZE41 magnesium alloys by laser cladding. Results Phys. 2019, 13, 102160. [CrossRef]

20. Viala, J.C.; Bosselet, F.; Laurent, V.; Lepetitcorps, Y. Mechanism and kinetics of the chemical interaction between liquid aluminium and silicon-carbide single crystals. J. Mater. Sci. 1993, 28, 5301-5312. [CrossRef]

21. Lloyd, D.J. Particle reinforced aluminium and magnesium matrix composites. Int. Mater. Rev. 1994, 39, 1-23. [CrossRef]

22. Lee, J.-C.; Park, S.-B.; Seok, H.-K.; Oh, C.-S.; Lee, H.-I. Prediction of Si contents to suppress the interfacial reaction in the SiCp/2014 Al composite. Acta Mater. 1998, 46, 2635-2643. [CrossRef]

23. Wu, H.; Cui, X.P.; Geng, L.; Fan, G.H.; Pang, J.C.; Wei, L.S. Fabrication and characterization of in-situ TiAl matrix composite with controlled microlaminated architecture based on $\mathrm{SiC} / \mathrm{Al}$ and Ti system. Intermetallics 2013, 43, 8-15. [CrossRef]

24. Lu, X.-H.; Yang, Y.Q.; Liu, C.X.; Yan, C.H.; AI, Y.L. Kinetics and mechanism of interfacial reaction in SCS-6 Sic continuous fiber-reinforced Ti-A1 intermetallic matrix composites. Trans. Nonferrous Met. Soc. China 2006, 16, 77-83. [CrossRef]

25. Schuster, J.C.; Palm, M. Reassessment of the binary Aluminum-Titanium phase diagram. J. Phase Equilibria Diffus. 2006, 27, 255-277. [CrossRef]

26. Lim, C.Y.H.; Lim, S.C.; Gupta, M. Wear behaviour of SiCp-reinforced magnesium matrix composites. Wear 2003, $255,629-637$. [CrossRef]

27. Reddy, L.; Preston, S.P.; Shipway, P.H.; Davis, C.; Hussain, T. Process parameter optimisation of laser clad iron based alloy: Predictive models of deposition efficiency, porosity and dilution. Surf. Coat. Technol. 2018. [CrossRef]

28. Torres, B.; Taltavull, C.; López, A.J.; Campo, M.; Rams, J. Al/SiCp and Al11Si/SiCp coatings on AZ91 magnesium alloy by HVOF. Surf. Coat. Technol. 2015. [CrossRef] 
29. Torres, B.; Rodrigo, P.; Campo, M.; Ureña, A.; Rams, J. Oxy-acetylene flame thermal spray of Al/SiC p composites with high fraction of reinforcements. J. Therm. Spray Technol. 2009, 18, 642-651. [CrossRef]

30. Rodrigo, P.; Campo, M.; Torres, B.; Escalera, M.D.; Otero, E.; Rams, J. Microstructure and wear resistance of Al-SiC composites coatings on ZE41 magnesium alloy. Appl. Surf. Sci. 2009, 255, 9174-9181. [CrossRef] 